\title{
Prevalence of human immunodeficiency virus and hepatitis $C$ virus among French prison inmates in 2010: a challenge for public health policy
}

\author{
C Semaille (c.semaille@invs.sante.fr) ${ }^{1}$, Y Le Strat ${ }^{1}$, E Chiron ${ }^{1}$, K Chemlal $^{2}$, M A Valantin ${ }^{2}$, P Serre ${ }^{3,4}$, L Caté5, C Barbier ${ }^{5}$, \\ $M$ Jauffret-Roustide ${ }^{1}$, the Prevacar Group ${ }^{6}$ \\ 1. Institut de Veille Sanitaire, Saint-Maurice, France \\ 2. Centre Hospitalier de la Pitié Salpetrière, Paris, France \\ 3. Unité de consultations et de soins ambulatoires, Centre Hospitalier le Mans, Le Mans, France \\ 4. Associations des Professionnels de Santé Exerçant en Prison (APSEP), France \\ 5. Direction Générale de la Santé, Paris, France \\ 6 . The members of the group are listed at the end of the article
}

Citation style for this article:

Semaille C, Le Strat Y, Chiron E, Chemlal K, Valantin MA, Serre P, Caté L, Barbier C, Jauffret-Roustide M, the Prevacar Group. Prevalence of human immunodeficiency virus and hepatitis C virus among French prison inmates in 2010: a challenge for public health policy. Euro Surveill. 2013;18(28):pii=20524. Available online: http:// www.eurosurveillance.org/ViewArticle.aspx?Articleld=20524

Article submitted on 31 August 2012 / published on 11 July 2013

We evaluated prevalence of human immunodeficiency virus (HIV) and hepatitis C virus (HCV) among prison inmates in France in 2010, in a cross-sectional singleday study based on a two-stage design. Sampling favoured larger establishments and included all types of prisons. Establishments were stratified by geographical region. Estimates were adjusted by poststratification of the total population of inmates in France. From 60,975 inmates in all 188 prisons on the sampling day, 2,154 were selected from 27 prisons, and 1,876 questionnaires completed. HIV prevalence was estimated at $2.0 \%$ (95\% confidence interval $(\mathrm{Cl})$ : 0.9-4.2), 2.6\% (95\% Cl: $0.7-8.8$ ) in women and $2.0 \%$ (95\% Cl: $0.9-4.3$ ) in men; $75 \%$ of inmates were receiving treatment for HIV. HCV prevalence was estimated at $4.8 \%(95 \% \mathrm{Cl}: 3.5-6.5)$ and was higher for women (11.8\%; 95\% Cl: 8.5-16.1) than men (4.5\%; 95\% Cl: 3.3-6.3). Almost half of HCV-infected inmates had chronic hepatitis C and $44 \%$ were receiving or had received treatment. HIV and HCV prevalence was six times higher than in the general population, and $2.5 \%$ of inmates had viraemic hepatitis $C$. The moment of incarceration provides an ideal opportunity for testing and treating, limiting spread of HCV and improving patients' prognosis.

\section{Introduction}

Infectious diseases are more prevalent in prison than in the general population, in particular human immunodeficiency virus (HIV) and hepatitis C. This is well documented in the international literature [1-5]. In France, foreign nationals represent $18 \%$ of admissions to French prisons, and more than half of these entrants originate from countries with a generalised HIV epidemic and from regions with high or medium hepatitis $\mathrm{C}$ virus (HCV) endemicity [6]. Since 1 January 2009, drug-trafficking offences have accounted for nearly $14 \%$ of convicted prisoners.
Published prevalence data are usually taken from studies conducted on small numbers of prisons or performed in single regions [7-14]. Previous HIV and HCV prevalence studies in French prisons were either conducted in a single region or did not contain information on the characteristics of the infected persons [15-20]. Implementing epidemiological studies in a prison environment presents more challenges than studies in the community, notably because of ethical considerations [21]. National data on HIV and HCV prevalence are however essential to implement prevention interventions and to improve screening and treatment for these two chronic conditions.

In this article, we report the results of a cross-sectional, single-day study based on two-stage sampling of prison establishments and inmates that was conducted in 2010 (Prévacar survey). Estimates of HIV and $\mathrm{HCV}$ infection prevalence were produced for the entire prison population, and by sex, age and continent of birth.

\section{Methods}

Target population

The eligible population for the survey comprised any individual aged over 18 and held in prison on the sampling day (15 May 2010) in metropolitan France and/or in French overseas departments (Antilles, French Guiana and Reunion Island). Prisoners on licence or parole on the sampling day were excluded from the survey.

\section{Sample size calculation}

The number of individuals for inclusion in the study was calculated to take into account the proportion of prisoners receiving opiate substitute treatments (estimated 
at $10 \%)$, the absolute level of precision required in the estimates ( $2 \%)$, and the expected design effect produced by the two-stage sampling design employed. The necessary sample size was 1,300 subjects, and 2,154 people were randomly selected in the prison establishments.

\section{Sampling design}

The French national prison service has a complete listing of prison establishments in France, and an exhaustive national database of prison inmates which is updated several times per day. Prisoners in the national database are assigned a unique identification number.

To limit the number of prison establishments, we implemented a two-stage sampling design instead of using simple random sampling. Prison establishments and prisoners were selected at the first and second stage, respectively. At the first stage, the exhaustive list of prison establishments was stratified according to ten geographical regions in France, i.e. covering the nation's territory. Within each region, establishments were further stratified to take into account the type of establishment (short, medium or long sentences, female-only or male-only). Establishments were chosen using ordered systematic sampling with unequal probabilities, proportional to the number of prisoners. Establishments for women and in certain priority regions were deliberately oversampled. At the second stage prisoners were selected by simple random sampling using the unique identification number in the national database of people in French prisons on the sampling day.

\section{Data collection}

The study did not use biological testing. Instead, for each person sampled, an anonymous individual questionnaire was completed by the Prévacar researchers or by health professionals based in the prison establishments using information in medical records. Proposing HIV and hepatitis C testing for all prisoners on admission to prison is mandatory in France, and French guidelines recommend that this offer be repeated periodically during prison stays.

The questionnaire also collected information on modes of transmission, clinical stage, treatment, viral load, $\mathrm{CD} 4$ lymphocyte count, and hepatic fibrosis. Additional information concerning continent of birth, socioeconomic status and employment before imprisonment was collected from the national prisoner database and merged with the questionnaire data using the unique identification number.

\section{Definition of cases}

A prison inmate was considered to be HIV infected when their medical record contained one of the following items: a positive ELISA test for HIV infection or a positive Western blot or a $\mathrm{CD}_{4}$ lymphocyte count or HIV viral load. A prison inmate was considered to be HCV infected when their medical record contained one of the following elements: a positive ELISA test for HCV or a positive HCV RNA detection in the previous 12 months.

\section{Ethical considerations}

To preserve the anonymity of subjects, a random number (different from the unique prison identification number mentioned above) was assigned to each selected prisoner. Prior to the study, the 2,154 people randomly selected in the prison establishments were informed individually of their selection and information on the study was posted publicly. At this point, prisoner refusal to take part in the survey could be communicated verbally or by returning a reply coupon to the medical team. The survey was approved by an ethics committee (no. 909331) and conformed to the principles embodied in the Declaration of Helsinki.

\section{Statistical analysis}

Analyses took into account the weighted sample design, i.e. oversampling for size and type of establishment, and estimates were adjusted by post-stratification on the total prison population [22] $(n=60,975$ on the sampling day) using available prison data (including sex, age group, continent of birth and geographical prison region) recorded for all prisoners in the national prisoner database on the date of sampling. Post-stratification took into account the national distribution of inmates by type of establishment.

This means that even for persons whose medical records did not contain a biological test result, i.e. unknown HIV and/or unknown HCV status, the following information was available: sex, age, continent of birth and prison establishment type (short, medium or long term sentences, female-only or male-only). Univariate and multivariate analyses (using logistic regression) were performed to compare sex and age of persons whose medical records contained a biological test result (for HIV or HCV) with those whose records did not contain such a result.

All analyses were performed using STATA 11 software.

\section{Results}

On the sampling day (15 May 2010), the total number of French prison establishments (for prisoners with short, medium and long sentences) equalled 188 and held 60,975 people. Of these, 27 prisons were randomly selected with specific oversampling conditions, from which 2,154 prison inmates were selected.

\section{Characteristics of the prison population}

in France on the sampling day

The majority of prisoners were men (97\%), and the average age of prison inmates was 34 years (interquartile range: $25-42$ years; standard deviation: 0.56 ). People born in France accounted for $76 \%$ of inmates, 
Estimated number of prison inmates infected with human immunodeficiency virus or hepatitis $\mathrm{C}$ virus, and prevalence by sex, age group, and continent of birth, France, May $2010(\mathrm{n}=1,876)$

\begin{tabular}{|c|c|c|c|c|c|}
\hline & $\begin{array}{l}\text { Study participants } \\
n^{\mathrm{a}}\end{array}$ & $\begin{array}{l}\text { HIV prevalence } \\
\%(95 \% \mathrm{CI})\end{array}$ & $\begin{array}{l}\text { HIV-infected inmates } \\
n^{\mathrm{b}}\end{array}$ & $\begin{array}{c}\text { HCV prevalence } \\
\%(95 \% \mathrm{Cl})\end{array}$ & $\begin{array}{l}\text { HCV-infected inmates } \\
n^{b}\end{array}$ \\
\hline Total & 1,876 & $2.0(1.0-4.2)$ & 1,234 & $4.8(3.5-6.5)$ & 2,927 \\
\hline \multicolumn{6}{|l|}{ Sex ${ }^{c}$} \\
\hline Males & 1,607 & $2.0(0.9-4.3)$ & 1,173 & $4.5(3.3-6.3)$ & 2,658 \\
\hline Females & 267 & $2.6(0.7-8.8)$ & 61 & $11.8(8.5-16.1)$ & 239 \\
\hline \multicolumn{6}{|l|}{ Age group $^{d}$} \\
\hline $18-21$ & 162 & 0 & 0 & 0 & 0 \\
\hline $22-25$ & 328 & $1.1(0.1-7.7)$ & 110 & $1.0(0.2-4.5)$ & 97 \\
\hline $26-30$ & 369 & $1.7(0.3-8.3)$ & 216 & $2.3(1.3-4.1)$ & 290 \\
\hline $31-40$ & 471 & $3.2(1.1-8.6)$ & 538 & $6.8(3.9-11.3)$ & 1,137 \\
\hline $41-50$ & 332 & $3.7(1.3-10.3)$ & 357 & $11.6(7.2-18.1)$ & 1,093 \\
\hline$\geq 50$ & 203 & $0.2(0.0-1.66)$ & 13 & $4.5(1.5-12.3)$ & 310 \\
\hline \multicolumn{6}{|l|}{ Continent of birth } \\
\hline France & 1,388 & $1.1(0.4-2.5)$ & 487 & $5.0(3.7-6.7)$ & 2,306 \\
\hline Sub-Saharan Africa & 90 & $15.4(6.6-31.8)$ & 522 & 0 & 0 \\
\hline North Africa & 149 & $3.2(0.4-24.6)$ & 166 & $5.9(2.3-14.3)$ & 294 \\
\hline Americas & 94 & $3.5(0.8-13.5)$ & 58 & 0 & 0 \\
\hline Asia & 31 & 0 & 0 & $12.4(2.1-48.2)$ & 139 \\
\hline Eastern Europe & 59 & 0 & 0 & $12.3(4.2-30.9)$ & 188 \\
\hline Western Europe & 47 & $0.04(0.005-0.4)$ & 1 & 0 & 0 \\
\hline
\end{tabular}

$\mathrm{Cl}$ : confidence interval; HCV: hepatitis C virus; HIV: human immunodeficiency virus.

a Number of observations in the sample.

b Extrapolated number of inmates, taking into account the weight sampling design and an adjustment by post stratification on the total prison population.

Sex unknown for two inmates.

d Age group and continent of birth were unknown for 11 and 18 cases, respectively.

while those born in north Africa and sub-Saharan Africa accounted for $9 \%$ and $5 \%$, respectively. For people born in eastern Europe and western Europe the percentages were $3.4 \%$ and $2.7 \%$, respectively.

\section{Study population}

Of the 2,154 prisoners included, 57 refused to take part in the survey. Questionnaires completed from medical records numbered 1,876 ( $87 \%)$, one questionnaire per prisoner, and represented 1,607 men and 267 women; sex was unknown for two inmates. Non-completed questionnaires included 221 cases for whom the medical records could no longer be consulted at the time of the survey, because the prisoner's conditions of imprisonment had changed in the period since sampling.

Of the 1,876 questionnaires used, information on HIV and HCV infection status was missing from $28 \%$ and $30 \%$ of records, respectively.

Comparison of persons with and without biological test result in their medical records In the univariate and multivariate analysis, prisoners whose medical records did not contain any information on HIV or HCV status were not significantly different from those whose medical records did, in terms of sex, age, and continent of birth (data not shown). However, HIV or HCV test results were two to four times as often absent from medical records of prisoners held in establishments for short and medium length sentences than of those held in prisons for long sentence prisoners.

\section{HIV prevalence and characteristics of HIV-infected persons}

HIV prevalence

HIV prevalence was estimated at $2.0 \%$ (95\% confidence interval (Cl): 1.0-4.2) (Table). Prevalence was higher in women than for men, $2.6 \%$ (95\% Cl: $0.7-8.8$ ) and $2.0 \%$ (95\% Cl: 0.9-4.3), respectively, but the difference was not significant. HIV prevalence increased with age up to 50 years from $0 \%$ among the 18-21 year-olds to $3.7 \%$ among the $41-50$ year-olds. HIV prevalence varied according to continent of birth, being highest among individuals born in sub-Saharan Africa (15.4\%). Among those born in France, HIV prevalence was 1.1\% and was not significantly different from that estimated for people born in North Africa (3.2\%) and those born in the Americas (3.5\%). No inmate born in Asia or eastern Europe was infected with HIV in our study. 
Characteristics and treatment of $\mathrm{HIV}$-infected prisoners Twenty-six individuals were identified as HIV-infected, with a mean age of 36 years (95\% Cl: 30-41.8). HIVinfected women were significantly older than men (44 years; $95 \% \mathrm{Cl}: 43-46)$ versus 35 years ( $95 \% \mathrm{Cl}: 29-42$ ). For a large proportion $66.4 \%(95 \% \mathrm{Cl}: 46.1-82.0)$ the mode of transmission was unknown. When this information was available, heterosexual intercourse was the transmission mode in the majority of cases $(74.7 \%$; 95\% Cl: 15.5-98.0).

The mean time since diagnosis of seropositivity was nine years (range: $4.7-13.5$ years), and $24 \%$ of HIVinfected prisoners had been diagnosed during imprisonment. Nearly one third (28.4\%, 95\% Cl: 9.3-60.4) of inmates had been diagnosed with acquired immunodeficiency syndrome (AIDS), 55.3\% (95\% Cl: 26.5-80.9) were asymptomatic and $16.4 \%$ (95\% Cl: 2.0-65.0) were symptomatic (non-AIDS). Three quarters of all HIV-infected had CD4 lymphocyte counts below 350/ $\mathrm{mm}^{3}$ (74\%; 95\% Cl: 44.3-90.8), 8\% (95\% Cl: 1.7-3.4) between $350 / \mathrm{mm}^{3}$ and $500 / \mathrm{mm}^{3}$, and $18.2 \%(95 \% \mathrm{Cl}$ : 5.5-45.8) had CD4 above 500/ $\mathrm{mm}^{3}$.

A majority of HIV-positive inmates (75\%) were receiving antiretroviral treatment for HIV at the time of the survey. Among inmates with a $\mathrm{CD}_{4}$ count below 350/ $\mathrm{mm}^{3}$, the proportion of people receiving antiretroviral treatment was $72 \%$.

\section{$\mathrm{HCV}$ prevalence and characteristics of $\mathrm{HCV}$-infected persons}

HCV prevalence

$\mathrm{HCV}$ prevalence was estimated at $4.8 \%(95 \% \mathrm{Cl}$ : 3.5-6.5) and increased significantly with age up to 50 years, from $0 \%$ in the age group 18-21 years to $11.6 \%$ in the age group 41-50 years. Prevalence was significantly higher among women than among men, $11.8 \%$ (95\% Cl: 8.5-16.1) and 4.5\% (95\% Cl: 3.3-6.3), respectively (Table). Prevalence varied by continent of birth, being highest among individuals born in Asia (12.4\%) and in eastern Europe (12.3\%). Prevalence among people born in France versus north Africa was not significantly different, $5.0 \%$ and $5.9 \%$, respectively. Inmates born in sub-Saharan Africa and the Americas were not infected with HCV in our study.

Characteristics and treatment of $\mathrm{HCV}$-infected prisoners In all, 63 people were identified as HCV-infected. Their mean age was 40.7 years ( $95 \% \mathrm{Cl}: 37-44)$, which was older than the HCV-seronegative individuals ( 34.3 years). HCV seropositive women were, younger than males (38 versus 41 years). The main mode of transmission was drug use $(70.2 \% ; 95 \% \mathrm{Cl}: 48.9-85.3)$. In HCV-infected prisoners, $8.2 \%(95 \% \mathrm{Cl}: 1.6-32.7)$ of transmission was due to blood transfusion and tattooing. The transmission mode was unknown for $22.0 \%$ (95\% Cl: $11.5-37.0)$ of the cases.
The mean time since HCV diagnosis was 6.8 years (3.8-9.8 years), and $21.2 \%$ (95\% Cl: $9.4-41.2$ ) of HCVinfected prisoners had been diagnosed during imprisonment. Overall, $44 \%$ (95\% Cl: $23.3-68.2$ ) of prisoners with HCV had received, or were receiving, treatment.

HCV RNA quantification was reported in the medical records of the majority of HCV prisoners (information missing from $6 \%$ of records), and was positive for almost half of them (46\%; 95\% Cl: 27.3-66.5). Nearly $2.5 \%$ of prison inmates had viraemic HCV.

Among prisoners with chronic hepatitis, i.e. with a persistent positive HCV RNA quantification, approximately half (41\%) [18-68] had undergone an evaluation for fibrosis by invasive or non-invasive methods in the previous 12 months and $36 \%$ were currently receiving treatment.

The prevalence of HIV- HCV co-infection among inmates was low (0.08\%; 95\% Cl: 0.00-0.65).

\section{Discussion}

This study is the first to estimate HIV and HCV prevalence among all prison inmates in France and to describe the characteristics of those infected. National HIV prevalence, estimated at $2 \%$, corresponded to 1,233 HIV-infected persons in the total prison population of 60,975 in mainland France and overseas. HCV prevalence, estimated at $4.8 \%$, corresponded to 2,927 HCV-infected persons, in most cases contaminated through drug use.

Our study of prison establishments and prison inmates based on a two-stage sampling design and poststratification adjustment, enabled us to produce HIV and HCV estimates for the entire prison population in French and French overseas prisons i.e. including those not included in the sample. Prevalence estimates were produced for a number of categories, notably sex, age, and continent of birth. Indeed, this methodology could be used to estimate national prevalence in other countries, subject to the availability of a sampling frame comprising an exhaustive list of prison establishments and a list of prison inmates.

A number of limitations of this study need to be noted. Firstly, no biological tests were performed in our study because performing biological tests for research purposes in France requires informed written consent of participants. Currently, ethical committees in France consider that a request for 'informed' consent is incompatible with the status of being a prisoner, i.e. persons who are deprived of their liberty. This position could change in the future. Therefore, the HIV and HCV infection status was obtained from medical records. Although HIV and HCV testing is routinely offered to all prisoners in France, information about the status of these infections was missing from $30 \%$ of medical records. The absence of a serological test result from the medical records does not necessarily mean that 
a test was not performed or offered; a test may have been performed but the result not recorded, or it may have been offered but refused by the prisoner, or performed as part of an anonymous and free medical visit. However, although the proportion not supplying this information was non-negligible, this does not necessarily mean our estimates were biased, since multivariate analysis of inmates without a serological result showed no significant difference in terms of sex, age or continent of birth, variables usually associated with HIV and HCV infection in the literature. Test results were more often lacking in medical records in establishments for short-term and medium-term sentences. This may have occurred because shorter incarceration periods limit the available time for testing.

Secondly, a high proportion of medical records (66\%) for HIV infected persons had no information about transmission mode. This is perhaps due to physicians' awareness of the sensitive nature of recording such data in prisons, e.g. homosexuality is still a taboo subject in prisons. Finally, another limitation of the study is the lack of collected variables associated with HIV and/or HCV transmission such as high-risk behaviours, tattooing etc. and the lack of information about the frequency of imprisonment.

HIV and HCV prevalence among prisoners in France is approximately six times higher than in the general population, an observation consistent with those for other countries $[3,5,9]$. In 2009, HIV prevalence in the general French population was estimated at $0.35 \%$ [23], while in 2004, the prevalence of anti-HCV antibodies in the population was estimated at $0.8 \%(95 \% \mathrm{Cl}$ : $0.6-1.1)[24]$.

HIV prevalence in prisoners of high-income countries range from $0 \%$ in prisons in Denmark and Northern Ireland $[13,25]$ to $8-10 \%$ in Italy and Portugal $[26,27]$. HIV prevalence among French prison inmates is close to that observed for prisons in North America, ranging from $1 \%$ to $2.5 \%$ according to the year of the study $[1,4,5,8,11,28,29]$ and higher than the $0.4 \%$ reported in the United Kingdom [30,31] and in Australia [32,33]. To date, French studies in the published international literature have been based on multi-round surveys conducted in a single prison establishment in Marseille in south-eastern France, with prevalences of $4 \%-11 \%$ depending on the year $[9,15,16]$ and a single-round survey in a single prison establishment in Caen, in northwestern France (prevalence o\%) [19]. Therefore, it is not possible to compare results from these surveys, conducted in a single establishment, with our HIV prevalence estimate conducted at a national level.

HCV prevalence in prison inmates of high-income countries also varies widely; an explanation may be differences in the proportions of inmates who use drugs. HCV estimates range from $1 \%$ to $50 \%[3,4,7,8,11-14,25-$ $27,30,32,34]$. In France, three studies [19,20,35] found prevalence rates between $4 \%$ and $6.9 \%$ in 2003 , which are close to that observed in our study.

There is strong consensus in the literature that HIV and HCV prevalence is consistently higher among female prisoners, probably reflecting drug use $[3,5,7,11,36]$. Among the female prisoners in the Prévacar survey, almost one in 10 was infected with HCV. In addition, our study found that HIV and HCV prevalence increased with age, which is also consistent with published literature. Prevalence rates also varied depending on the prisoners' continent of birth, although the small numbers mean that the rates associated with continent of birth were subject to greater inaccuracy (this is reflected by large confidence intervals). HIV prevalence among prisoners born in sub-Saharan Africa was particularly high, over $15 \%$, partly owing to the generalised HIV epidemic in that region. Similarly, HCV prevalence was high, over $12 \%$ among prisoners born in Asia, a region with high HCV endemicity, and in eastern Europe, where there is a large-scale epidemic among drug users.

The majority of HIV-infected prisoners in this study had been diagnosed seropositive several years earlier and were at an advanced stage of immunodeficiency: $75 \%$ had a CD4 count below $350 / \mathrm{mm}^{3}$ when the study took place. Among those $75 \%$ inmates, three quarters were receiving antiretroviral treatment. Similarly, HCVpositive prisoners had been diagnosed with hepatitis several years before the study took place (on average seven years). Nearly half of them had developed chronic hepatitis. Overall, half of the HCV-infected prisoners had received or were receiving treatment for hepatitis $C$. These results suggest that treatment for HCV and HIV infections are available for inmates in French prisons, but could be reinforced among inmates with $\mathrm{CD}_{4}$ counts below $350 / \mathrm{mm}^{3}$ and among those with active HCV infection.

The method developed for this survey enabled us to estimate HIV and HCV prevalences in French prisons at a national level. It could be used for other infectious diseases, in particular tuberculosis and hepatitis B. Nearly $2.5 \%$ of prison inmates in France have viraemic $\mathrm{HCV}$, and the risk of HCV transmission to other prisoners is exacerbated by widespread risk behaviours such as tattooing and the sharing of shaving equipment $[3,37]$. It is important that prison establishments maximise efforts to limit the spread of HCV by introducing prevention and harm reduction measures $[38,39]$. The moment of incarceration provides an ideal opportunity for testing and treating HIV and HCV in order to limit the spread of HCV and to improve the prognosis of infected patients. 
Members of the Prévacar Group:

J Bouscaillou, G Braz, M Clément, E Chaigne, JC Cognet, D de Galard, S Essid, B Faliu, C Gasiglia, L Lavin, D Legrand, E Lucas, C Michon, F Moreau, H Morfini, R Nouiouat, F Pilorgé, P Pouyanne, C Vuldy.

\section{Acknowledgements}

We would like to thank the French national prison service for its support (Dominique de Galard, Jean-Claude Cognet, Dimitri Legrand). We would also like to thank the staff of all the participating prison health facilities, Martine Clément, the physicians who conducted the survey in the prisons (Bernard Faliu, Lionel Lavin, Christophe Michon from the Ministry of health), and the members of the survey steering committee (Gregory Braz, Emeline Chaigne, Sandra Essid, Caroline Gasiglia, Hélène Morfini, François Moreau, Rhida Nouiouat, Fabrice Pilorgé, Pierre Pouyanne, Chantal Vuldy). We also thank Charlotte Verdot. Finally, our thanks to Jude Sweeney for the English revision and editing of the manuscript.

\section{Funding}

This work was supported by the French Ministry of Health and the Institut de Veille Sanitaire (InVS). The funding for the study came jointly from the Ministry of Health and the InVS. The survey steering committee included representatives of the prison physicians' professional organisations, prison authorities, infectious disease specialists, and representatives of treatment providers and civil society (anti-AIDS agencies).

\section{References}

1. Fazel S, Baillargeon J. The health of prisoners. Lancet. 2011;377(9769):956-65. http://dx.doi.org/10.1016/ S0140-6736(10)61053-7.

2. Dolan K, Kite B, Black E, Aceijas C, Stimson GV. HIV in prison in low-income and middle-income countries. Lancet Infect Dis. 2007;7(1):32-41. http://dx.doi.org/10.1016/ S1473-3099(06)70685-5.

3. Vescio MF, Longo B, Babudieri S, Starnini G, Carbonara S, Rezza G, et al. Correlates of hepatitis C virus seropositivity in prison inmates: a meta-analysis. J Epidemiol Community Health. 2008;62(4):305-13. http://dx.doi.org/10.1136/ jech.2006.051599. PMid:18339822.

4. Gough E, Kempf MC, Graham L, Manzanero M, Hook EW, Bartolucci A, et al. HIV and hepatitis B and C incidence rates in US correctional populations and high risk groups: a systematic review and meta-analysis. BMC Public Health. 2010;10:777. http://dx.doi.org/10.1186/1471-2458-10-777. PMid:21176146. PMCid:PMC3016391.

5. Weinbaum CM, Sabin KM, Santibanez SS. Hepatitis B, hepatitis C, and HIV in correctional populations: a review of epidemiology and prevention. AIDS. 2005;19 Suppl 3:S41-6. http://dx.doi.org/10.1097/01.aids.0000192069.95819.aa. PMid:16251827.

6. Direction de l'administration pénitentiaire. [Prison Directorate]. Les chiffres clés de l'administration pénitentiaire au 1er janvier 2009. [Key figures of the prison administration on 1 January 2009]. Paris: Ministère de la Justice; $2009.15 \mathrm{p}$. French. Available from: http://www.justice.gouv.fr/art_pix/ Chiffresclesjanv2009.pdf

7. Baillargeon J, Wu H, Kelley MJ, Grady J, Linthicum L, Dunn K. Hepatitis C seroprevalence among newly incarcerated inmates in the Texas correctional system. Public Health. 2003;117(1):438. http://dx.doi.org/10.1016/So033-3506(02)00009-4

8. Macalino GE, Vlahov D, Sanford-Colby S, Patel S, Sabin K, Salas C, et al. Prevalence and incidence of HIV, hepatitis B virus, and hepatitis $C$ virus infections among males in Rhode Island prisons. Am J Public Health. 2004;94(7):1218-23. http://dx.doi.org/10.2105/AJPH.94.7.1218. PMid:15226146. PMCid:PMC1448424.

9. Rotily M, Weilandt C, Bird SM, Kall K, Van Haastrecht HJ, Iandolo E, et al. Surveillance of HIV infection and related risk behaviour in European prisons. A multicentre pilot study. Eur
J Public Health. 2001;11(3):243-50. http://dx.doi.org/10.1093/ eurpub/11.3.243. PMid:11582600.

10. Allwright S, Bradley F, Long J, Barry J, Thornton L, Parry JV. Prevalence of antibodies to hepatitis $B$, hepatitis $C$, and HIV and risk factors in Irish prisoners: results of a national cross sectional survey. BMJ. 2000;321(7253):78-82. http:// dx.doi.org/10.1136/bmj.321.7253.78. PMid:10884256. PMCid:PMC 27426.

11. Calzavara L, Ramuscak N, Burchell AN, Swantee C, Myers $T$, Ford $P$, et al. Prevalence of HIV and hepatitis $C$ virus infections among inmates of Ontario remand facilities. CMAJ. 2007;177(3):257-61. http://dx.doi.org/10.1503/cmaj.060416. PMid:17664449. PMCid:PMC1930192.

12. Poulin C, Alary M, Lambert G, Godin G, Landry S, Gagnon H, et al. Prevalence of HIV and hepatitis $C$ virus infections among inmates of Quebec provincial prisons. CMAJ. 2007;177(3):25256. http://dx.doi.org/10.1503/cmaj.060760. PMid:17664448. PMCid:PMC1930200.

13. Danis K, Doherty L, McCartney M, McCarrol J, Kennedy H. Hepatitis and HIV in Northern Ireland prisons: a cross-sectional study. Euro Surveill 2007;12(1):pii=674. Available from: http:// www.eurosurveillance.org/ViewArticle.aspx?Articleld $=674$

14. Pallás J, Fari-as-Alvarez C, Prieto D, Llorca J, DelgadoRodríguez M. Risk factors for monoinfections and coinfections with HIV, hepatitis B and hepatitis C viruses in northern Spanish prisoners. Epidemiol Infect. 1999;123(1):95-102. http:// dx.doi.org/10.1017/S0950268899002538. PMid:10487645. PMCid:PMC 2810732.

15. Rotily M, Galinier-Pujol A, Obadia Y, Moatti JP, Toubiana $P$, Vernay-Vaisse C, et al. HIV testing, HIV infection and associated risk factors among inmates in south-eastern French prisons. AIDS. 1994;8(9):1341-4. http://dx.doi. org/10.1097/00002030-199409000-00020. PMid:7802991.

16. Rotily M, Vernay-Vaisse C, Bourliere M, Galinier-Pujol A, Rousseau S, Obadia Y. HBV and HIV screening, and hepatitis B immunization programme in the prison of Marseille, France. Int J STD AIDS. 1997;8(12):753-9. http://dx.doi. org/10.1258/0956462971919228. PMid:9433949.

17. Hedouin V, Gosset D. Infection par le virus de l'hépatite $C$ en milieu carcéral. [Infection with hepatitis $C$ virus in a prison environment. A prospective study in Loos-lez-Lille, France]. Gastroenterol Clin Biol. 1998;22(1):55-8. French. PMid:9762167.

18. Claudon-Charpentier A, Hoibian M, Glasser P, Lalanne $\mathrm{H}$, Pasquali JL. La population toxicomane incarcérée: séroprévalences du virus d'immunodéficience humaine et des virus des hépatites $B$ et $C$ peu après la mise sur le marché de la buprénorphine. [Drug-addicted prisoners: seroprevalence of human immunodeficiency virus and hepatitis $B$ and $C$ virus soon after the marketing of buprenorphine]. Rev Med Interne. 2000;21(6):505-9. French. http://dx.doi.org/10.1016/ So248-8663(00)89225-5

19. Verneuil L, Vidal IS, Ze BR, Vabret A, Petitjean I, Leclercq R, et al. Prevalence and risk factors of the whole spectrum of sexually transmitted diseases in male incoming prisoners in France. Eur J Clin Microbiol Infect Dis. 2009;28(4):409-13. http://dx.doi.org/10.1007/s10096-008-0642-z. PMid:18998176.

20. Remy AJ. Amélioration du dépistage et du traitement de l'hépatite $C$ en prison. Enquête comparative entre 2000 et 2003. [Hepatitis C in prison settings: screening and therapy are improving. Comparative survey between 2000 and 2003]. Presse Med. 35(9 Pt 1):1249-54. French.

21. Rich JD, Wohl DA, Beckwith CG, Spaulding AC, Lepp NE, Baillargeon J, et al. HIV-related research in correctional populations: now is the time. Curr HIV/AIDS Rep. 2011;8(4):288-96. http://dx.doi.org/10.1007/s11904-011-00953. PMid:21904902. PMCid:PMC3208731.

22. Tillé Y. Sampling algorithms.Springer Series in Statistics. New York: Springer, 2006. PMCid:PMC2360768.

23. Yeni $P$ (editor). Rapport 2010. Prise en charge médicale des personnes infectées par la VIH: Recommandations du groupe d'experts. [2010 report. Medical care of persons infected with HIV: recommendations of the expert group]. Paris: La documentation Française; 2010. p. 24-34. French. Available from: http://www.sante.gouv.fr/IMG/pdf/Rapport_2010_sur_ la prise en charge medicale des personnes infectees par le_VIH_sous_la_direction_du_Pr-_Patrick_Yeni.pdf

24. Meffre C, Le Strat Y, Delarocque-Astagneau E, Dubois F, Antona $D$, Lemasson JM, et al. Prevalence of hepatitis B and hepatitis C virus infections in France in 2004: social factors are important predictors after adjusting for known risk factors. J Med Virol. 2010;82(4):546-55. http://dx.doi.org/10.1002/jmv.21734. PMid:20166185.

25. Christensen PB, Krarup HB, Niesters HG, Norder H, Georgsen J. Prevalence and incidence of bloodborne viral infections among Danish prisoners. Eur J Epidemiol. 2000;16(11):1043-9. http:// dx.doi.org/10.1023/A:1010833917242. PMid:11421474. 
26. Babudieri S, Longo B, Sarmati L, Starnini G, Dori L, Suligoi B, et al. Correlates of HIV, HBV, and HCV infections in a prison inmate population: results from a multicentre study in Italy. J Med Virol. 2005;76(3):311-7. http://dx.doi.org/10.1002/ jmv.20375. PMid:15902712.

27. Barros H, Ramos E, Lucas R. A survey of HIV and HCV among female prison inmates in Portugal. Cent Eur J Public Health. 2008;16(3):116-20. PMid:18935775.

28. Wilper AP, Woolhandler S, Boyd JW, Lasser KE, McCormick $\mathrm{D}$, Bor DH, et al. The health and health care of US prisoners: results of a nationwide survey. Am J Public Health. 2009;99(4):666-72. http://dx.doi.org/10.2105/ AJPH.2008.144279. PMid:19150898. PMCid:PMC 2661478.

29. VanHandel M, Beltrami JF, MacGowan RJ, Borkowf CB, Margolis AD. Newly identified HIV infections in correctional facilities, United States, 2007. Am J Public Health. 2012;102 Suppl 2:S201-4. http://dx.doi.org/10.2105/AJPH.2011.300614. PMid:22401522.

30. Weild AR, Gill ON, Bennett D, Livingstone SJ, Parry JV, Curran L. Prevalence of HIV, hepatitis B, and hepatitis $C$ antibodies in prisoners in England and Wales: a national survey. Commun Dis Public Health. 2000;3(2):121-6. PMid:10902255.

31. Edwards A, Curtis S, Sherrard J. Survey of risk behaviour and HIV prevalence in an English prison. Int J STD AIDS. 1999;10(7):464-6. http://dx.doi.org/10.1258/0956462991914474. PMid:10454182.

32. Butler TG, Dolan KA, Ferson MJ, McGuinness LM, Brown PR, Robertson PW. Hepatitis B and C in New South Wales prisons: prevalence and risk factors. Med J Aust. 1997;166(3):127-30. PMid:9059433.

33. Crofts N, Stewart T, Hearne P, Ping XY, Breshkin AM, Locarnini SA. Spread of bloodborne viruses among Australian prison entrants. BMJ. 1995;310(6975):285-8. http://dx.doi.org/10.1136/bmj.310.6975.285. PMid:7866168. PMCid:PMC2548691.

34. Saiz de la HP, Marco A, Garcia-Guerrero J, Rivera A. Hepatitis C and $B$ prevalence in Spanish prisons. Eur J Clin Microbiol Infect Dis. 2011;30(7):857-62. http://dx.doi.org/10.1007/s10096-0111166-5. PMid:21274586.

35. Direction de l'Hospitalisation et de l'Organisation des Soins (DHOS). [Directorate of Hospitalisation and Care Organization]. Enquête un jour donné sur les personnes détenues atteintes par le VIH et le VHC en milieu pénitentiaire: résultats de l'enquête de juin 2003. [Survey on a given day on prisoners infected with HIV and HCV in prisons: results of the survey in June 2003]. Paris: DHOS; 2004 . French. Available from: http:// www.sante.gouv.fr/enquete-un-jour-donne-sur-les-personnesdetenues-atteintes-par-le-vih-et-le-vhc-en-milieu-penitentiaire. html

36. Wu ZH, Baillargeon J, Grady JJ, Black SA, Dunn K. HIV Seroprevalence among newly incarcerated inmates in the Texas correctional system. Ann Epidemiol. 2001;11(5):342-6. http:// dx.doi.org/10.1016/S1047-2797(01)00210-1.

37. Teutsch S, Luciani F, Scheuer N, McCredie L, Hosseiny $\mathrm{P}$, Rawlinson W, et al. Incidence of primary hepatitis C infection and risk factors for transmission in an Australian prisoner cohort. BMC Public Health. 2010;10:633. http:// dx.doi.org/10.1186/1471-2458-10-633. PMid:20964864. PMCid:PMC 2975656

38. Michel L, Carrieri MP, Wodak A. Harm reduction and equity of access to care for French prisoners: a review. Harm Reduct J. 2008;5:17. http://dx.doi.org/10.1186/1477-7517-5-17. PMid:18495018. PMCid:PMC 2430551.

39. Michel L, Jauffret-Roustide M, Blanche J, Maguet O, Calderon $C$, Cohen J, et al. Limited access to HIV prevention in French prisons (ANRS PRI2DE): implications for public health and drug policy. BMC Public Health. 2011;11:400. http:// dx.doi.org/10.1186/1471-2458-11-400. PMid:21619573. PMCid:PMC3128573. 